\section{Whole, Unmilled Olives Can Be Used to Determine their Oil Content by Nuclear Magnetic Resonance}

\author{
Carmen del Río and \\ Ana M a Romero
}

AdDitional indeX WORDS. NM $R$, fruit, flesh, oil percentage, dehydration, Olea europaea.

Summary. Several experiments showed that whole, unmilled olives (Olea europaea L.) could be dehydrated in 42 hours in a forced-air oven at $105^{\circ} \mathrm{C}\left(221^{\circ} \mathrm{F}\right)$, so that they could be used in determining their oil content in a nuclear magnetic resonance (N M R) analyzer. After confirming that the N MR and the official Soxhlet methods estimate the same oil percentages in milled olives, linear regression analysis also showed that N M R provides the same oil percentage results with milled and unmilled fruit. This new method avoids sample manipulation before dehydrating the fruit, making it possible to work with olive samples weighing as little as $70 \mathrm{~g}$ (2.47 oz). It allows for processing a large number of samples in a short period of time and may be also used with unmilled fruit flesh. The method is also very useful for screening genotypes, either from germplasm banks or progenies from olive breeding programs, and for evaluating cultivars in comparative trials.

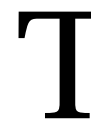

heSoxhlet istheofficial method (Lynk, 1975) used to determine the oil content of both oil seeds and olive fruit. H owever, it requires too much samplemanipulation, a long extraction time and a lot of

Dept. Olivicultura y Arboricultura Frutal, CIFA "Alameda del O bispo" (J unta deAndalucía), A partado 3092, 14080 Cordoba, Spain.

We acknowledge D. H idalgo, U. Gutiérrez, and I. Lorite, for their laboratory and field assistance. The cost of publishing this paper was defrayed in part by the payment of page charges. Under postal regulations, this paper therefore must be hereby marked advertise ment solely to indicate this fact. laboratory space. A modified extraction system has been recently proposed (Avidan et al., 1997), but it still needs more than $48 \mathrm{~h}$, the use of a solvent and more sample manipulation. A refractometric system is not safe because of the carcinogenic properties of chloronaftalene, used as solvent ( $L$ avee et al., 1988).

The nuclear magnetic resonance (N M R ) method haswidely substituted the Soxhlet procedure as it provides the same accuracy in the results, not needing to extract the oil from the material, and requiring much less sample manipulation and time to get the oil content reading, just $24 \mathrm{~s}$ (Frías et al., 1991; Romero Guzmán and Gracián Tous, 1977).

The N M R method has been routinely used to determine the oil content of intact seeds of many oil crop species (Romero G uzmán and G racián Tous, 1976), but olive samples still have to be milled before drying them in an oven at $105^{\circ} \mathrm{C}(221 \stackrel{\circ}{\circ})$ until constant mass. In the only attempt so far to use whole olives (Romero Guzmán and Gracián Tous, 1977) it was concluded that it was very difficult to dry the fruit completely in a short time. The authors also concluded that the water remaining in the fruit was the main reason for the aleatory differences of up to $\pm 3 \%$ that they observed between the oil percentages provided by N M R readingsof either wholefruit, dried during $2.5 \mathrm{~h}$ under infrared rays, or milled fruit, dried at $105^{\circ} \mathrm{C}(221$ $\left.{ }^{\circ} \mathrm{F}\right)$ until constant mass. Another reason they pointed out was that the cracks produced in the epidermis of the fruit by the rapid drying process could give rise to possible fruit oil losses.

M illing a sample takes $\approx 20 \mathrm{~min}$. Theuse of whole, unmilled oliveswould greatly diminish the time needed to prepare samples before dehydration to determine its oil content. This is always important, especially with germplasm bankshaving limited personnel (del Río and Caballero, 1994). In addition, to characterize olive cultivars the dry flesh mass oil percentage is more stable than the dry fruit mass ( $\mathrm{H}$ ermoso et al., 1997). Theobjective of thiswork wasto study whether it would be possible to eliminate all the moisture content from whole, unmilled olives and from unmilled olive flesh, so that they could be used as such to determine their oil content by an N M R analyzer. 


\section{Materials and methods}

All the olive samples were taken from different cultivars growing in the World O live Germplasm Bank established at the experimental farm of CIFA "Alameda del Obispo", Córdoba, Spain (T able 1). Cultivars were always selected for showing important differences in their pomological parameters (del Río and Caballero, 1994).

Sample preparation. All fruit sampleswerehomogenized in thelaboratory by fruit color and size to minimize the possible differences observed when comparing unmilled with milled olives. Each sample consisted of at least $2 \mathrm{~kg}(4.4 \mathrm{lb})$ of fresh fruit. M ean fruit mass was determined in each sample from three groups of 100 fruits each. The mass of the endocarp was determined from one of thethree 100 fruit groupsand theflesh to stoneratio was figured out from the mean fruit and endocarp masses. Afterwards the remaining fruit of each sample was randomly divided into two subsamples of the same size. O ne subsample was milled and the resulting paste mixed, as in the standard procedure (Lynk, 1975). Then, according to the experiment, either four, three or two 70-g (2.47-oz) replicationsweretaken from each subsample. The whole-fruit replications were randomly taken from the corresponding subsample. Both the milled and unmilled replications were individually deposited in Petri dishes covered by a plastic film resistant to high temperatures, and then dried in a forced-air oven at $105 \circ \mathrm{C}$ (221 ㅇ) until reaching constant mass.

After weighing the dried replications to determine the moisture content they had lost, the oil percentages of milled and unmilled dry olives were measured in an NMR Oxford 4000 analyzer (Oxford Analytical Instru- ments, Abingdon, England) equipped with a $150-\mathrm{mL}$ (5.07-fl oz) sample vase, which was set up to perform three readings per replication. E ach reading took $8 \mathrm{~s}$. The analysis mode of the N M R was as follows: radio frequency level 350 , audio frequency gain 400 , gate width 1.5 , analysis time per measurement $8 \mathrm{~s}, 3$ measurements per sample and calibration time $15 \mathrm{~s}$. The N M R used a linear calibration passing through the origin, thus requiring just one reference standard to determine the slope. In this work $62.13 \mathrm{~g}(2.187$ oz) of virgin olive oil was $100 \%$. E ach sample dry mass was entered and results were determined on a signal per gram basis.

The average value and standard deviation of both moisture and oil percentages were determined in both subsampletypes (milled and unmilled) by taking into account the number of replications used in the corresponding

T able 1. C ultivars and number of samples studied to test that it is possible to use whole olives to determine their oil content by nuclear magnetic resonance.

\begin{tabular}{|c|c|c|c|c|c|}
\hline Cultivar & $\begin{array}{c}\text { No. } \\
\text { samples }\end{array}$ & C ultivar & $\begin{array}{c}\text { No. } \\
\text { samples }\end{array}$ & Cultivar & $\begin{array}{c}\text { No. } \\
\text { samples } \\
\end{array}$ \\
\hline Adramitini & 1 & Frantoio A. Corsini & 1 & M eloncillo & 1 \\
\hline Aglandaou & 1 & G enovesa & 1 & M eski & 1 \\
\hline Alfafara & 2 & Gordal del Centro & 1 & Mollar D e Cieza & 1 \\
\hline Amargoso & 1 & Gordal Sevillana & 3 & M orona & 1 \\
\hline Arbequina & 2 & Gordalejo & 1 & M orrut & 1 \\
\hline Arbosana & 1 & Grappolo & 2 & $\mathrm{~N}$ abali & 1 \\
\hline Ascolana Tenera & 1 & H ojiblanca & 5 & N evadillo Blanco de Jaen & 1 \\
\hline Asnal & 1 & I mperial & 1 & N evado Azul & 1 \\
\hline Ayrouni & 2 & Itrana & 1 & N evado Basto & 1 \\
\hline Blanqueta & 1 & Izmir Sofralik & 1 & Oblonga & 10 \\
\hline Bolvino & 1 & Jabaluna & 1 & O cal & 1 \\
\hline Borriolenca & 1 & Kaissy & 2 & Olivo De M aura & 1 \\
\hline Bouteillan & 1 & Kalamon & 1 & O uslati & 2 \\
\hline Caballo & 1 & Konservolea & 3 & Pajarero de Lucena & 1 \\
\hline Cakir & 1 & Koroneiki & 3 & Picual & 6 \\
\hline Callosina & 2 & Leccino & 1 & Picudo & 2 \\
\hline Caninese & 1 & Lechin de Granada & 1 & Racimal & 2 \\
\hline Cañivano Blanco & 1 & Lechin de Sevilla & 2 & Racimal Jaen & 1 \\
\hline Carrasqueño de Elvas & 1 & Lentisca & 2 & Rapasayo & 1 \\
\hline Carrasqueño de Jumilla & 1 & Levantinka & 1 & Razzola & 2 \\
\hline Cellina & 2 & Lloron de I znalloz & 1 & Real Sevillana & 1 \\
\hline Chemlal de Kabilye & 1 & Lloron de Ronda & 1 & Rechino & 1 \\
\hline Chorreao de M ontefrio & 1 & Luckes & 1 & Redonda de M ora de Toledo & 1 \\
\hline Chorruo & 1 & Macho de Jaen & 2 & Redonda de Torrijos & 1 \\
\hline Chorruo de Castro & 1 & M adural & 1 & Sevillenca & 1 \\
\hline Coratina & 1 & M anzanilla C acereña & 1 & Sigoise & 1 \\
\hline Corbella & 1 & M anzanilla de Agua & 2 & Sourani & 1 \\
\hline Cornicabra & 2 & $M$ anzanilla del $C$ entro & 2 & Tempranillo de Calatayud & 2 \\
\hline Cornicabra de M érida & 1 & M anzanilla de Jaen & 1 & Verdale & 1 \\
\hline D atilero & 1 & M anzanilla de $M$ ontefrio & 1 & Verdalon & 1 \\
\hline Dolce Agogia & 1 & M anzanilla del Piquito & 1 & Verdial de Badajoz & 1 \\
\hline Dulzal de Carmona & 1 & M anzanilla de Sevilla & 4 & Verdial de H uevar & 1 \\
\hline Empeltre & 1 & M anzanilla de Tortosa & 2 & Verdilla de Calatayud & 2 \\
\hline Escarabajuelo de Posadas & 1 & M anzanilla de Zahara & 1 & Zalmati & 1 \\
\hline Escarabajuelo de U beda & 1 & M arteño de la Carlota & 1 & & \\
\hline Frantoio & 1 & M aurino & 2 & & \\
\hline
\end{tabular}


Table 2. Removed moisture and oil content of unmilled dried olives before and after mashing and drying them for $24 \mathrm{~h}$.

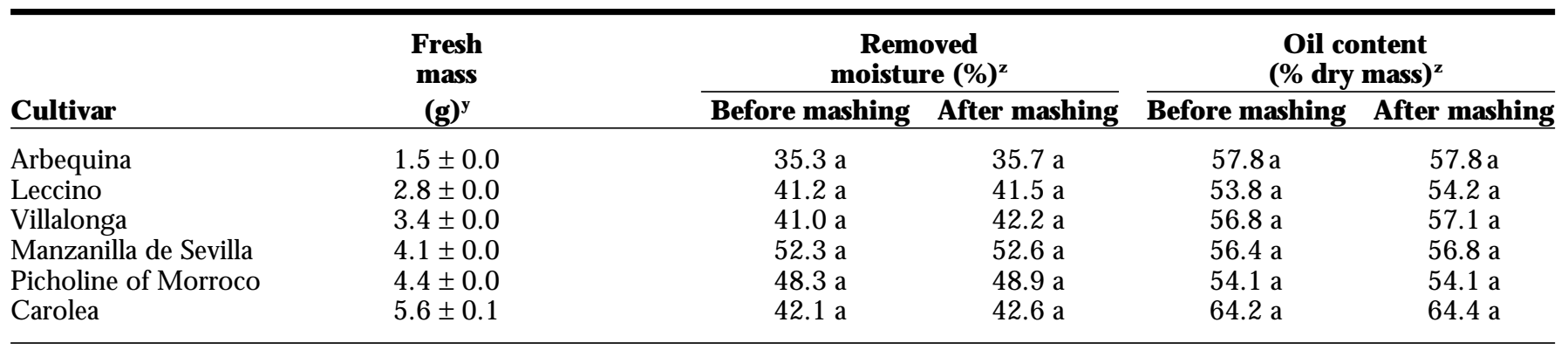

zM ean of three replications. M ean separation within row for moisture and oil percentages, by Student'st test (P $\leq 0.05)$.

$\mathrm{yM}$ ean $\pm \mathrm{SE}$, of three 100 -fruit groups ( $28.35 \mathrm{~g}=1.0 \mathrm{oz}$ ).

experiment. The related means were compared by the Student'st test. Correlation coefficients and linear regressions between treatments were also calculated.

Correlation between nMr and SOXHLET METHODS. To ensure that the analyzer was adequately calibrated, olivefruit samplesfrom 24 cultivars were analyzed. The procedure consisted in milling $\approx 0.5 \mathrm{~kg}(1.1 \mathrm{lb})$ of fresh fruit from each cultivar and in drying a 70$\mathrm{g}$ replication of the obtained paste at $105^{\circ} \mathrm{C}\left(221^{\circ} \mathrm{F}\right)$ until reaching constant weight. The olive dry mass oil percentage was determined, first by theN M R method and then by Soxhlet (Frías et al., 1991).

DehydRATING Whole, UNMILLED OLIVES. Three $70-g$ replications of unmilled olive samples from six cultivars were dried until constant massand evaluated as per moisture and oil content under NMR. To ensure that unmilled fruit was dried completely, the olives were then mashed, breaking their endocarps, and reevaluated for moisture and oil content after drying them again for $24 \mathrm{~h}$ more.

Determining the time to DRY UNMILLED OLIVEs. O live samples from eight cultivars of different pomologi- cal characteristics: fruit and endocarp masses, flesh to stone ratio, maturity stage, and oil and water content, were divided into two equal subsamples. Four 70-g replications were prepared from both subsamples, milled and unmilled. The moisture content removed from the replications during the drying process wasmeasured at 18 , 24,42 , and 48 h. O il content was determined when the corresponding replications reached constant mass.

Determining nMr sample size. The average value and standard deviation of four, three, two, and one 70-g replications of both milled and unmilled fruit were compared. Additionally, to determine whether it would be possible to further diminish the fruit mass used, one of those 70-g replications of unmilled and dry fruit was divided into two equal parts and their oil contents determined again.

ACCURACY AND RELIABILITY OF THE PROPOSED METHOD WTTH UNMILLED FRUIT. O live fruit samples (154) were taken from 106 cultivars selected to achieve the highest possible variability in their pomological parameters. Three replications per subsample were used and dried for either 24 or 42 h, respectively, for milled and unmilled olives, as determined by the corresponding previous results.

USE OF UNMILLED FRUIT FLESH. Working with another two cultivars, after dividing each sample into two subsamples, the endocarps were removed from the olives by using a manual pitting machine that did not destroy the flesh. The flesh moisture and dry mass oil contents were determined by using two 70-g replications per subsample, milled and unmilled.

\section{Results}

Correlation between nmr and SOXHLET. The high determination Coefficient $\left(r^{2}=0.98, P \leq 0.001\right)$ of the linear regressions between the two methods $(y=-1.419+1.026 x)$ confirmed that the NMR method estimates the same olive dry mass oil content as the Soxhlet system does. Furthermore, eight of the 24 samples used, those showing extreme and medium values, were read by N M R several more times during the season to verify that the analyzer was al ways adequately calibrated.

Dehydration of UNmilled olives. To dry the unmilled olives at $105 \circ \mathrm{C}$ ( $221^{\circ} \mathrm{F}$ ) until reaching constant mass removed all the fruit moisture in every

Table 3. Drying period and percentage of moisture and dry mass oil content of milled and unmilled olive subsamples from eight cultivars of different pomological characteristics.

\begin{tabular}{|c|c|c|c|c|c|c|c|c|c|}
\hline \multirow[b]{2}{*}{ Cultivar } & \multirow{2}{*}{$\begin{array}{l}\text { Maturity } \\
\text { index }^{y}\end{array}$} & \multirow{2}{*}{$\begin{array}{c}\text { Fresh } \\
\text { mass } \\
(\mathbf{g})^{x}\end{array}$} & \multirow{2}{*}{$\begin{array}{c}\text { Flesh } \\
\text { to stone } \\
\text { ratio } \\
\end{array}$} & \multicolumn{2}{|c|}{$\begin{array}{r}\text { Drying } \\
\text { time }(\mathbf{h})\end{array}$} & \multicolumn{2}{|c|}{$\begin{array}{c}\text { Moisture } \\
\text { removed }(\%)^{z} \\
\end{array}$} & \multicolumn{2}{|c|}{$\begin{array}{l}\text { Oil content } \\
(\% \text { dry mass })^{z} \\
\end{array}$} \\
\hline & & & & Milled & Unmilled & Milled & Unmilled & Milled & Unmilled \\
\hline
\end{tabular}

zM ean of four replications per subsample. M ean separation within rows, for moisture and oil percentages, by Student'st test (P $\leq 0.05$ ).

$\mathrm{y}_{1}$ = green, 4 = black.

${ }^{\mathrm{X}} \mathrm{M}$ ean $\pm \mathrm{SE}$, of three 100 -fruit groups ( $\left.28.35 \mathrm{~g}=1.0 \mathrm{oz}\right)$.

Hortlechnology $•$ O ctober-D ecember 1999 9(4) 
one of the six samples used. This was confirmed by no further water loss after mashing the olives until cracking their endocarps and drying those olives for $24 \mathrm{~h}$ more (Table 2). Similarly, this extra drying period applied to the mashed olives did not significantly change their N M R oil content readings.

Dehydration time. No relationship was found between the time needed to remove all the moisture from an olive fruit and its pomological parameters, even in the case of milling the fruit (Table 3). In fact, only $18 \mathrm{~h}$ were needed to dehydrate milled olives of different types, such as 'Zalmati' and 'Koroneiki', with small mass and low flesh to stone ratio; 'Jabaluna', with medium value in both parameters; and 'Escarabajuelo', with large fruit and high flesh to stone ratio. $\mathrm{H}$ owever, $24 \mathrm{~h}$ were required for other cultivars also having small fruit mass and low flesh to stone ratio, like 'Verdilla de C alatayud', and for others of medium fruit size and medium or high flesh to stone ratio, like ' $G$ ordal Sevillana' and 'Picual', respectively for flesh to stone ratio. Similarly, $42 \mathrm{~h}$ were needed to dehydrate unmilled olives of all types, with the exception of those of 'E scarabjuelo', which needed only $18 \mathrm{~h}$. Finally, olives in any one of the two maturity stages used, green and black epidermis, did not differ in the drying period they needed, both in milled and unmilled types.

On the other hand, milled and unmilled subsamples of these cultivars showed the same moisture and dry mass oil content when reaching constant mass. No relationship was found between the times needed to dehydrate them and their water and oil contents, that ranged from $55 \%$ to $72 \%$ and from $29 \%$ to $55 \%$, respectively. As 24 and $42 \mathrm{~h}$ were the longest times needed to dehydrate milled and unmilled olives, respectively, thesedrying periods were adopted in the remaining work to be developed for testing the proposed hypothesis.

NMR SAMPLE SIZE. Within every cultivar, the evaluated dry mass oil contentswereal waysthesame, whether taking into account one, two, three, or four replications of $70 \mathrm{~g}(2.47 \mathrm{oz})$, either of milled or unmilled olives (Table 4). The standard error (SE) was always very small and changed erratically when increasing the number of replications. With milled olives the SE decreased, starting from two replications, for 'G ordal Sevillana', 'J abaluna', 'Koroneiki', 'Verdilla de Calatayud', and 'Zalmati', but increased for the other three tested cultivars, 'Ayrouni', 'E scarabajuelo', and 'Picual'. H owever, with unmilled olives, the SE diminished for 'E scarabajuelo', 'Picual', and 'Zalmati' and increased for all the other cultivars. M oreover, in the case of whole olives no significant differences were observed in comparing the oil content readings of $70-\mathrm{g}$ replications $(y)$ and those of just half that mass ( $x$ ), which showed a linear regression of $r^{2}$ $=0.99, P \leq 0.001 ; y=1.112 x$.

ACCURACY AND RELIABILITY OF THE PROPOSED METHOD WITH UNMILLED FRUIT. The moisture and dry massoil content readings did not significantly differ between milled and unmilled olives in the 154 samples studied (Table 5). Their pomological characteristicswere very different: fruit mass ranged from

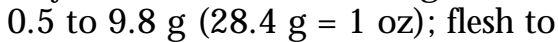
stone ratio from 2 to 12.2; and water and dry mass oil content from $33.6 \%$ to $75.6 \%$ and $12.6 \%$ to $56.6 \%$, respectively. H owever, the correlation coefficients $(r)$ between the milled and unmilled fruit subsamples for the different pomological parameters ranged from 0.74 to 0.99 and from 0.98 to 0.99 (all $P \leq 0.001$ ) for moisture and oil content, respectively. M oreover, there was a good linear regression between the two methods (Fig. 1), and no significant differenceswereobserved among the oil percentages provided by three, two or just one replication of milled $(r=0.99 ; P \leq 0.001)$ and unmilled $(r=0.99 ; P \leq 0.001)$ olives, with any of the 154 samples used.

UsE OF UNMILLED FRUIT FLESH. No significant differences in either moisture or oil content results were observed between milled or unmilled olive flesh samples of 'Conservolea' and 'Sourani' (Table 6).

\section{Discussion}

NM R is widely used in determining the oil content of olive samples, both in research and olive mill laboratories, asit estimates the same contents than the official Soxhlet method in less time (Romero Guzmán and Gracián Tous, 1977, Frias et al., 1991). O ur results confirm this.

The normal analytical procedure

T able 4. Oil content, as percentage of olive fruit dry mass, of eight cultivars as affected by the number of replicates per subsample in milled, or unmilled olives.

\begin{tabular}{|c|c|c|c|c|c|}
\hline \multirow[b]{2}{*}{ Cultivar } & \multirow[b]{2}{*}{ Subsample } & \multicolumn{4}{|c|}{ No. of $70-g(2.47-0 z)$ replications } \\
\hline & & 1 & 2 & 3 & 4 \\
\hline Gordal Sevillana & M illed & $27.6 \mathrm{a}$ & $28.5 \pm 0.9 a^{2}$ & $28.4 \pm 0.5 \mathrm{a}$ & $28.5 \pm 0.4 a$ \\
\hline \multirow[t]{2}{*}{ Jabaluna } & $M$ illed & $42.5 \mathrm{a}$ & $43.0 \pm 0.5 \mathrm{a}$ & $43.1 \pm 0.3 \mathrm{a}$ & $42.9 \pm 0.2 \mathrm{a}$ \\
\hline & Unmilled & $42.4 \mathrm{a}$ & $42.4 \pm 0.0 \mathrm{a}$ & $42.8 \pm 0.4 a$ & $42.7 \pm 0.3 \mathrm{a}$ \\
\hline Ayrouni & M illed & 39.8 a & $39.8 \pm 0.1 \mathrm{a}$ & $39.7 \pm 0.1 \mathrm{a}$ & $39.2 \pm 0.5 \mathrm{a}$ \\
\hline Koroneiki & Unmilled & $37.6 \mathrm{a}$ & $37.6 \pm 0.0 \mathrm{a}$ & $37.3 \pm 0.3 a$ & $37.4 \pm 0.4 a$ \\
\hline \multirow[t]{2}{*}{ Escarabajuelo } & $M$ illed & $54.9 \mathrm{a}$ & $54.8 \pm 0.1 \mathrm{a}$ & $54.2 \pm 0.8 \mathrm{a}$ & $54.2 \pm 0.7 \mathrm{a}$ \\
\hline & Unmilled & $55.2 \mathrm{a}$ & $55.7 \pm 2.5 \mathrm{a}$ & $55.4 \pm 1.6 \mathrm{a}$ & $55.0 \pm 0.6 \mathrm{a}$ \\
\hline \multirow[t]{2}{*}{ Picual } & M illed & $47.5 \mathrm{a}$ & $47.6 \pm 0.1 \mathrm{a}$ & $47.2 \pm 0.4 \mathrm{a}$ & $47.1 \pm 0.3 \mathrm{a}$ \\
\hline & Unmilled & $46.9 \mathrm{a}$ & $46.6 \pm 0.4 a$ & $46.4 \pm 0.3 a$ & $46.6 \pm 0.3 a$ \\
\hline Verdilla & M illed & $31.3 \mathrm{a}$ & $30.8 \pm 0.5 a$ & $30.6 \pm 0.4 a$ & $30.4 \pm 0.3 a$ \\
\hline
\end{tabular}

zM ean $\pm \mathrm{SE}$. M ean separation within rows by Student's t test $(P \leq 0.05)$. 
Table 5. C orrelation coefficients $(r)$ between the moisture and oil percentages of milled and unmilled olive sub-samples of 154 samples (106 cultivars), arranged by intervals of variation within different pomological parameters.

\begin{tabular}{|c|c|c|c|c|c|c|c|}
\hline \multirow{2}{*}{$\begin{array}{l}\text { Pomological } \\
\text { parameter } \\
\text { and interval } \\
\text { of variation }\end{array}$} & \multirow{2}{*}{$\begin{array}{c}\text { No. of samples } \\
\text { (cultivars) }\end{array}$} & \multicolumn{3}{|c|}{ M oisture removed (\%) } & \multicolumn{3}{|c|}{ O il content ( $\%$ dry mass) } \\
\hline & & Milled & Unmilled & $r$ & Milled & Unmilled & $r$ \\
\hline \multicolumn{8}{|l|}{ Fruit color } \\
\hline Green & $11(7)$ & $50.6 a^{2}$ & $51.0 \mathrm{a}$ & $0.99^{* * *}$ & $38.3 \mathrm{a}$ & $38.0 \mathrm{a}$ & $0.99^{* * *}$ \\
\hline Purple & $11(8)$ & $60.2 a$ & $59.9 \mathrm{a}$ & $0.99^{* * *}$ & $39.9 \mathrm{a}$ & $39.5 \mathrm{a}$ & $0.99^{* * *}$ \\
\hline Black & $132(99)$ & $61.7 \mathrm{a}$ & $61.7 \mathrm{a}$ & $0.99^{* * *}$ & $41.9 \mathrm{a}$ & $42.0 \mathrm{a}$ & $0.99^{* * *}$ \\
\hline \multicolumn{8}{|l|}{ Fruit mass $(g)^{y}$} \\
\hline $0.5-2$ & $35(25)$ & $54.1 \mathrm{a}$ & $54.2 \mathrm{a}$ & $0.99^{* * *}$ & $41.3 \mathrm{a}$ & $41.0 \mathrm{a}$ & $0.99^{* * *}$ \\
\hline $2-4$ & 74 (57) & $61.4 \mathrm{a}$ & $61.5 \mathrm{a}$ & $0.99^{* * *}$ & $40.2 \mathrm{a}$ & $40.4 \mathrm{a}$ & $0.99^{* * *}$ \\
\hline $4-6$ & $26(24)$ & $64.4 \mathrm{a}$ & $64.1 \mathrm{a}$ & $0.97^{* * *}$ & $42.8 \mathrm{a}$ & $42.8 \mathrm{a}$ & $0.99^{* * *}$ \\
\hline $6-8$ & $12(11)$ & $66.9 a$ & $67.0 \mathrm{a}$ & $0.98^{* * *}$ & $48.2 \mathrm{a}$ & $48.0 \mathrm{a}$ & $0.99^{* * *}$ \\
\hline $8-9.8$ & $5(3)$ & $69.8 \mathrm{a}$ & $69.4 \mathrm{a}$ & $0.99^{* * *}$ & $36.6 \mathrm{a}$ & $36.4 \mathrm{a}$ & $0.99^{* * *}$ \\
\hline \multicolumn{8}{|c|}{ Flesh to stone ratio } \\
\hline $2-4$ & $22(15)$ & $54.5 \mathrm{a}$ & $54.8 \mathrm{a}$ & $0.99^{* * *}$ & $41.7 \mathrm{a}$ & $41.4 \mathrm{a}$ & $0.99^{* * *}$ \\
\hline $4-7$ & $68(52)$ & $60.8 \mathrm{a}$ & $60.6 \mathrm{a}$ & $0.98^{* * *}$ & $40.2 \mathrm{a}$ & $40.0 \mathrm{a}$ & $0.99^{* * *}$ \\
\hline $7-10$ & $41(30)$ & $64.6 \mathrm{a}$ & $64.8 \mathrm{a}$ & $0.98^{* * *}$ & $44.5 \mathrm{a}$ & $44.6 \mathrm{a}$ & $0.99^{* * *}$ \\
\hline $10-12.2$ & $4(3)$ & $66.4 \mathrm{a}$ & $65.8 \mathrm{a}$ & $0.99^{* * *}$ & $60.7 a$ & $60.4 a$ & $0.99^{* * *}$ \\
\hline \multicolumn{8}{|l|}{ M oisture (\%) } \\
\hline $33.6-50$ & $13(10)$ & $46.2 \mathrm{a}$ & $46.2 \mathrm{a}$ & $0.98^{* * *}$ & $43.4 \mathrm{a}$ & $43.4 \mathrm{a}$ & $0.99^{* * *}$ \\
\hline $50-60$ & $56(41)$ & $54.7 \mathrm{a}$ & $54.6 \mathrm{a}$ & $0.86^{* * *}$ & $44.6 \mathrm{a}$ & $44.8 \mathrm{a}$ & $0.98^{* * *}$ \\
\hline $60-70$ & $66(51)$ & $65.3 \mathrm{a}$ & $65.3 a$ & $0.94^{* * *}$ & $42.0 \mathrm{a}$ & $42.0 \mathrm{a}$ & $0.99^{* * *}$ \\
\hline $70-75.6$ & 19 (17) & $72.6 \mathrm{a}$ & $73.1 \mathrm{a}$ & $0.74^{* * *}$ & $29.3 a$ & $29.1 \mathrm{a}$ & $0.99^{* * *}$ \\
\hline \multicolumn{8}{|c|}{ O il (\% dry mass) } \\
\hline $12.6-30$ & $16(14)$ & $67.4 \mathrm{a}$ & $67.8 \mathrm{a}$ & $0.99^{* * *}$ & $24.0 \mathrm{a}$ & $23.9 \mathrm{a}$ & $0.99^{* * *}$ \\
\hline $30-40$ & $40(36)$ & $63.4 \mathrm{a}$ & $63.7 \mathrm{a}$ & $0.98^{* * *}$ & $36.1 \mathrm{a}$ & $36.1 \mathrm{a}$ & $0.95^{* * *}$ \\
\hline $40-50$ & $80(55)$ & $58.9 a$ & $58.8 \mathrm{a}$ & $0.98^{* * *}$ & $44.7 \mathrm{a}$ & $45.0 \mathrm{a}$ & $0.95^{* * *}$ \\
\hline $50-56.6$ & 18 (15) & $57.2 \mathrm{a}$ & $56.7 \mathrm{a}$ & $0.99^{* * *}$ & $54.6 \mathrm{a}$ & $54.4 \mathrm{a}$ & $0.99^{* * *}$ \\
\hline
\end{tabular}

$\mathrm{z}_{\mathrm{M}}$ ean of three replications for subsample. M ean separation within rows for moisture and oil percentages, by Student'st test $(P \leq 0.05)$

y28.35 g = $1.0 \mathrm{oz}$

${ }^{* * *}$ Significant at $\mathrm{P} \leq 0.001$.

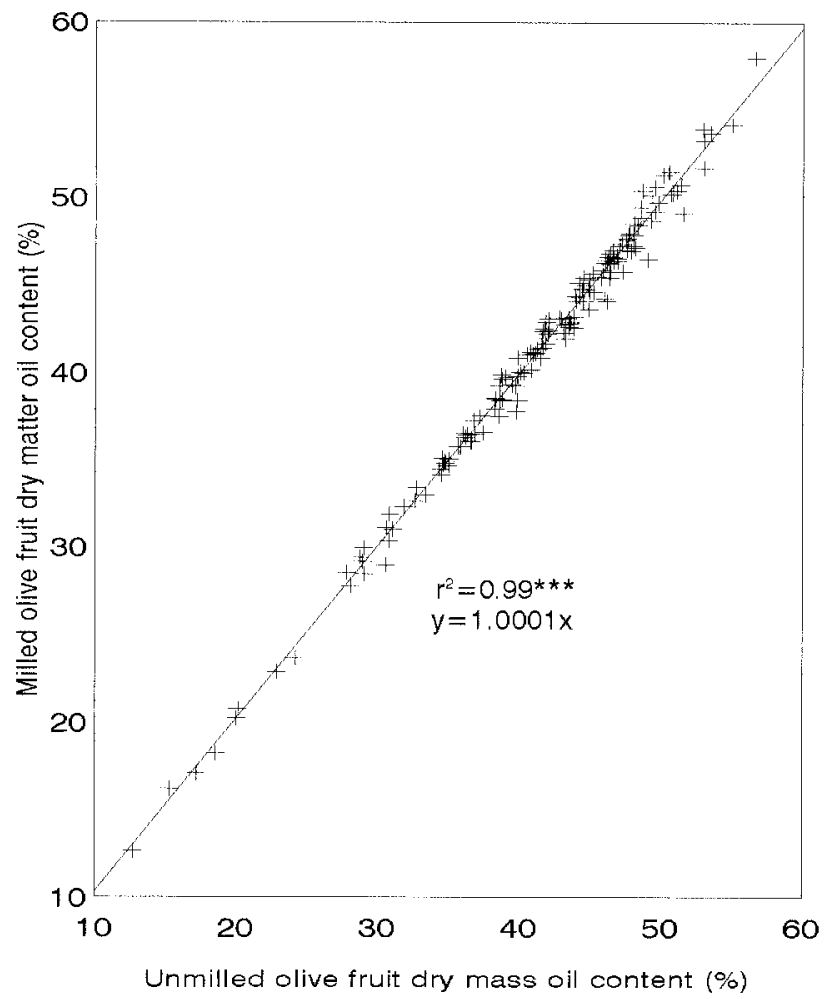

Fig. 1. Relationship between oil content of milled and unmilled olives from 154 samples (106 cultivars). M arked points indicate the mean values of three replications per subsamples ${ }^{* * *}$ Significant at $P \leq$ 0.001).

includes a good milling of the sample and its dehydration, as it has al ways been considered that unmilled, whole olives could not be completely dried, a condition required to use NMR for estimating oil content (Romero Guzmán y Gracián Tous, 1977). These authorscould not dehydrate completely the unmilled olives and concluded that it could be due to several factors: the high moisture of the olive, the fruit cuticle acting against the water vapor exit, the extreme difficulty in removing the water combined to some fruit components, and the occurrence of fruit skin cracks, that would allow for the exit of no-water compounds. H owever, in the present study whole, unmilled olives from different cultivars were completely dehydrated by drying them in an oven at $105^{\circ} \mathrm{C}\left(221^{\circ} \mathrm{F}\right)$ until reaching constant mass. The efficiency of the drying system used is shown by the moisture and oil content readings, which were the same before and after mashing the olives until cracking their endocarps and drying them again (Table 2). Therefore, the impossibility of dehydrating wholeolivescompletely should not be considered any longer as a difficulty to use them in determining their oil contents by N M R.

On the other hand, the lack of relationship between the time needed to completely dry different olive samples and any of their different pomological characteristicsindicatesthat it is not possible to foresee the time needed to dry whole olives of a given cultivar. The interaction between the studied characteristics and others not 
T able 6. Removed moisture and oil percentages of milled and unmilled olive flesh from two cultivars.

\begin{tabular}{|c|c|c|c|c|c|c|c|c|c|}
\hline \multirow[b]{2}{*}{ Cultivar } & \multirow{2}{*}{$\begin{array}{c}\text { Sample } \\
\text { no. }\end{array}$} & \multicolumn{2}{|c|}{$\begin{array}{c}\text { Fruit mass } \\
(\mathbf{g})^{z}\end{array}$} & \multicolumn{2}{|c|}{$\begin{array}{c}\text { Flesh to stone } \\
\text { ratio }^{z}\end{array}$} & \multicolumn{2}{|c|}{$\begin{array}{c}\text { Moisture } \\
(\%)^{y}\end{array}$} & \multicolumn{2}{|c|}{$\begin{array}{c}\text { Oil content } \\
\text { (\% dry mass) }^{\mathrm{y}}\end{array}$} \\
\hline & & Milled & Unmilled & Milled & Unmilled & Milled & Unmilled & Milled & Unmilled \\
\hline $\begin{array}{l}\text { Conservolea } \\
\text { Sourani }\end{array}$ & $\begin{array}{l}1 \\
2 \\
1 \\
2\end{array}$ & $\begin{array}{l}7.1 \\
7.0 \\
3.2 \\
3.8\end{array}$ & $\begin{array}{l}6.9 \\
7.1 \\
3.1 \\
3.8\end{array}$ & $\begin{array}{r}12.2 \\
12.5 \\
8.1 \\
8.0\end{array}$ & $\begin{array}{r}12.4 \\
12.2 \\
8.2 \\
8.0\end{array}$ & $\begin{array}{l}66.5 a \\
66.3 a \\
67.3 a \\
67.1 a\end{array}$ & $\begin{array}{l}66.3 a \\
66.3 a \\
67.3 a \\
66.0 a\end{array}$ & $\begin{array}{l}68.3 \mathrm{a} \\
68.3 \mathrm{a} \\
65.6 \mathrm{a} \\
66.1 \mathrm{a}\end{array}$ & $\begin{array}{l}67.9 a \\
68.4 a \\
64.4 a \\
65.4 a\end{array}$ \\
\hline
\end{tabular}

zValues estimated in the whole subsample $(28.35 \mathrm{~g}=1.0 \mathrm{oz})$.

yM ean of three replications. M ean separation within rows, for moisture and oil percentages, by Student'st test $(P \leq 0.05)$.

considered in this work could possibly be responsible for the different rates at which moisture is removed from different types of olives (Table 3). The differences in fruit texture and cuticle thickness (L avee, 1986) and the water linked to other compounds (Romero Guzmán and Gracián Tous, 1977) could be some of these other parameters. This hypothesis could also explain the different drying periods needed even for milled olives, in spite of their cellular structures being destroyed by the milling operation and the resulting paste well exposed to the heat in the oven.

T wenty-four hours was the minimum time required to make sure that fruit of every typewas dehydrated when working with milled olives. For unmilled samples $42 \mathrm{~h}$ should always beused in order to assure the complete fruit drynessor dehydration (Table 3), at least until a faster drying system could be available. The high correlation between the moisture percentages of milled and unmilled olives of all types, dehydrated within these time periods, confirms this conclusion (Table 5).

It is concluded that the substitution of milled by unmilled olives of all types is justified because their oil percentages are not significantly different ( Table 5) and they show a high correlation between them for all parameters and their intervals of variation. The good linear adjustment of the oil percentages obtained by the traditional and proposed methods (Fig. 1) confirms that it is possible to use whole olives to determine their oil content by NMR.

This new method avoids sample manipulation, so many samples can be processed in a short time if the fruit is placed in the oven every day up to 1400 HR. Their moisture and oil percentages will be determined at 0800 H R 2 d later.

Similarly, unmilled olive flesh can also be used to determine its oil content ( $T$ able 6 ). $T$ his possibility is very important for comparing genotypes, from either germplasm banks or progenies from breeding projects, as it has been established that dry flesh oil content is the more stable parameter to characterize olive genotypes by their oil yield (H ermoso et al., 1997).

Another advantage of the new method is that it needs less amount of fruit because there is no need to mill the olives. Effectively, at least $0.25 \mathrm{~kg}$ $(0.55 \mathrm{lb})$ of fresh olives are needed to get a good milling in the standard laboratory hammer mill, but $\approx 0.5 \mathrm{~kg}$ $(1.1 \mathrm{lb})$ is normally used to assure that the mill is clean from previous sample fruit before getting the needed paste to make up the 70-g (2.47-oz) replication to be dried. However, working with unmilled olives, a 70-g fruit sample is enough for the N M R analyzer with a 150-mL (5.07-fl oz) sample vase. M oreover, this work shows that the same apparatus can be used when having either 70 or only $35 \mathrm{~g}$ ( $1.23 \mathrm{oz})$ of fresh olives $\left(r^{2}=0.99, P \leq 0.001 ; y=\right.$ $1.112 x)$, as when working with the first crops of would-be new cultivars obtained in breeding projects. Another possibility for working with even less sampling material could be to use an NMR analyzer set up with a smaller sample vase.

Research laboratories normally work with fruit samples in the same maturity stage (del Río and C aballero, 1994). With this type of samples the use of justa 70 -g replication of unmilled olivesisreally enough to estimate their oil contents, as there is no increase in accuracy when using two, three or four replications (Table 4). This conclusion is also supported by the results of the 154 cultivars obtained by one, two or three replications $(r=0.99, \mathrm{P} \leq$ 0.001 ). When the sample is not so homogenous, as in commercial mills, the number of replications to be made from a determined sample should be decided according to the fruit variability.

\section{Literature cited}

A vidan, B., A. Agrodovitch, and S. Lavee. 1997. A reliable and rapid shaking extraction system for the determination of oil content in olive fruit. Olivae 67:44-47.

Del Río, C. and J.M. Caballero. 1994. Preliminary agronomical characterization of 131 cultivars introduced in the olive germplasm bank of Córdoba in March 1987. Acta H ort. 356:110-115.

F rías, L., A. García-O rtiz, M . H ermoso, A. Jimenez, M.P. Llavero del Pozo, J. Morales, M.T. Ruano, and M. U ceda. 1991. Analistas de laboratorio de almazara. Apuntes. Consejería de Agriculturay Pesca, J unta de Andalucía. Sevilla, Spain.

H ermoso, M., M. U ceda, L. Frías, and G. Beltrán. 1997. M aduración, p. 145-161. In: D. Barranco, R. Fernández-Escobar, and L. Rallo (eds.). El cultivo del olivo. 2nd ed. Mundi-Prensa and Junta de Andalucía, M adrid, Spain.

L avee, S. 1986. O live, p. 261-276. In: P.S. M onselise (ed.). $\mathrm{H}$ andbook of fruit set and development. CRC Press, Boca Raton, Fla.

L avee, S., M. Wodner, and B. A vidan. 1988. $A$ rapid refractometric method for determination of the oil content in olive (Olea europaea) fruit. Adv. H ort. Sci. 2:33-37.

Lynk, W.E. (ed.). 1975. O fficial and tentative methods of the American $\mathrm{O}$ il $\mathrm{Chem}$ ists' Society. Amer. O il Chem. Soc., Champaign, III.

Romero Guzmán, F. and J. Gracián Tous. 1976. A plicación delaresonanciamagnética nuclear a la determinación de la riqueza grasa en oleaginosas. I. Semillas de girasol, sojay cártamo. G rasasy A ceites 27 (6):373378.

Romero Guzmán, F. and J . Gracián Tous. 1977. Aplicación de la Resonancia M agnética N uclear a la determinación de riqueza grasa en oleaginosas. II. $D$ eterminación en aceitunas. Grasas y Aceites 28 (2):85-99.

Horllechnology • O ctober-D ecember 1999 9(4) 